\title{
UNCERTAINTY IN HISTORICAL LAND-USE RECONSTRUCTIONS WITH TOPOGRAPHIC MAPS
}

\author{
Dominik Kaim ${ }^{1}$, Jacek KozaK ${ }^{1}$, Krzysztof Ostafin ${ }^{1}$, Monika Dobosz ${ }^{1}$, Katarzyna \\ Ostapowicz ${ }^{1}$, Natalia Kolecka ${ }^{1}$, Urs Gimmi ${ }^{2}$ \\ ${ }^{1}$ Institute of Geography and Spatial Management, Jagiellonian University in Krakow, Poland \\ ${ }^{2}$ Research Unit Landscape Dynamics, Swiss Federal Institute for Forest, Snow and Landscape Research WSL, \\ Birmensdorf, Switzerland
}

Manuscript received: May 29, 2014

Revised version: July 29, 2014

Kaim D., Kozak J., Ostafin K., Dobosz M., Ostapowicz K., Kolecka N., Gimmi U., 2014. Uncertainty in historical land-use reconstructions with topographic maps. Quaestiones Geographicae 33(3), Bogucki Wydawnictwo Naukowe, Poznań, pp. 55-63, 2 tables, 4 figs. DOI 10.2478/quageo-2014-0029, ISSN 0137-477X.

AвSTRACT: The paper presents the outcomes of the uncertainty investigation of a long-term forest cover change analysis in the Polish Carpathians (nearly 20,000 km²) and Swiss Alps (nearly 10,000 $\mathrm{km}^{2}$ ) based on topographic maps. Following Leyk et al. (2005) all possible uncertainties are grouped into three domains - production-oriented, transformation-oriented and application-oriented. We show typical examples for each uncertainty domain, encountered during the forest cover change analysis and discuss consequences for change detection. Finally, a proposal for reliability assessment is presented.

KEY WORDS: forest cover change, uncertainty, topographic maps, the Carpathians, the Alps

Address of the corresponding author: Dominik Kaim, Institute of Geography and Spatial Management, Jagiellonian University in Krakow, Gronostajowa 7, 30-387 Krakow, Poland; e-mail: dkaim@gis.geo.uj.edu.pl

\section{Introduction}

Land-use change analysis based on cartographic information is always subject to uncertainty. The main reason is that maps are simplified models of reality (Veregin 1999). As noted by Plewe (2002), reality itself is very complex, but not uncertain, which implies that uncertainty is caused by either conceptualization, measurement or analysis processes. Map errors, differences in map instructions or interpretations cumulate with comparisons of different cartographic sources. Many methodologies and theoretical models deal with uncertainty in land-use research (Petit, Lambin 2002, Plewe 2002, Leyk et al. 2005, Pontius, Spencer 2005, Kunz 2006, Gregory, Healey
2007, Wulf, Rujner 2011, Wolski 2012), most of them, however, are tested on relatively small study areas and therefore it is not always easy to transfer their results when analysing a large portion of land.

In this study, we assess map uncertainty as a crucial aspect of a proper large-area map processing effort aiming at forest cover change analysis in the Polish Carpathians (nearly $20,000 \mathrm{~km}^{2}$ ) and a part of the Swiss Alps (nearly 10,000 $\mathrm{km}^{2}$ ) over the past $120-160$ years. To do this, we had to obtain, understand, estimate and process various maps based on the best possible and relatively homogeneous data sources covering the whole studied territory. Therefore, apart from uncertainty issues, we had to cope also with map 
availability and temporal coherence problems. In this paper we show crucial uncertainty issues encountered during our long-term forest cover change analysis. First, we introduce a conceptual framework of uncertainty investigation proposed by Leyk et al. (2005), and then we address this framework based on our research findings.

\section{Conceptual framework of uncertainty investigation}

Many definitions of uncertainty can be found in geospatial literature. Longley et al. (2001) define it as the acknowledgment and consideration of imprecisions in information. Zhang and Goodchild (2002) understand it as a measure of the difference between the data and the meaning attached to the data by the user. Fisher (2003) points out that uncertainty can be seen as a doubt about the information which is recorded at specific location. These definitions show the problem in a broad sense and do not refer directly to historical or multi-temporal data. By contrast, the conceptual framework proposed by Leyk et al. (2005) suits well to long-term land cover change analysis, as it was based on historical forest cover change investigation in Switzerland. Leyk et al. (2005) define the uncertainty in GIS as "the lack of knowledge about:

- objects of the real world due to erroneous measurement, vague definitions and concepts or unknown and ambiguous meaning,

- effects of transformations performed on the data,

- the latter's suitability for the intended application."

In case of historical maps, each of these aspects of uncertainty refers to one of three inter-related domains:

- production-oriented uncertainty;

- transformation-oriented uncertainty;

- application-oriented uncertainty.

First stage of any map comparison (e.g. in order to detect changes in land-use) is to understand what does a map show, and, equally important, what a map does not show. Being aware of map imprecision and its impact on research results, Leyk et al. (2005) argued that production-oriented uncertainty influences change detection analysis more than two other types. In the first domain, several aspects can be taken into account, e.g. spatial effects related to map production and generalisation or lack of knowledge about historical semantic models employed in mapping. Transformation-oriented uncertainty is closely related to processing error (Goodchild 1991) and may be triggered by scanning of paper maps, georeferencing and object extraction. Several aspects of transformation-oriented uncertainty are relatively easy to assess, e.g., accuracy of georeferencing based on control points could be expressed using Root Mean Square Error (RMSE). Application-oriented uncertainty arises due to differences in meanings of objects presented on maps and discrepancies between original and intended use of the maps which in some cases may show an inadequacy of comparison of historical and current data (Leyk et al. 2005).

Each of these three domains contains different aspects of uncertainty which have to be investigated separately. The overall uncertainty assessment aims at answering the question whether the sum of defined uncertainties is acceptable for a specific application.

\section{Historical maps used in the study}

In the Polish Carpathians our analysis aims at quantifying the forest cover dynamics over 120 years (mid-19 ${ }^{\text {th }}$ century - 1970s) starting with the Second Military Survey Map of the Habsburg Empire (scale 1:28,000). The Second Military Survey Map was the first empire-wide topographic map using a proper map projection (Timár 2004, Skaloš et al. 2011, Affek 2013), a generalisation of cadastral mapping (Franciscian Cadaster 1:2,880). The Polish Carpathians are presented on three different editions of the map. The oldest set covers two regions of Polish-Slovak borderland (Spiš and Orava) and was published between 1822-1824 (10 sheets). Additional 8 sheets covering the south-eastern part of Silesia were published between 1839-1940. The main part of the Second Military Survey Map presenting the Polish Carpathians was created between 1861-1862 (112 sheets) and has the highest quality. Regardless the edition, forests were marked in grey colour with a dark boundary outline. 
The intermediate data set was the Polish Military Map (WIG) in scale 1:100,000, published between 1934-1938. At the time of creation, the map was considered as an excellent example of the modern cartographic design and valuable source of information (Krassowski 1973). Forest patches were marked in green colour with a dotted boundary line.

The latest data set was the Polish Topographic Map $(1: 25,000)$ created between $1975-1983$ by the Head Office of Geodesy and Cartography (Główny Urząd Geodezji i Kartografii, GUGIK). Forests were marked in green colour with a dotted boundary line.

All above-mentioned maps have been widely used in land use and land cover change research in the Carpathians (e.g., Kozak 2003, Warcholik 2005, Kaim 2009, Ostafin 2009, Affek 2011). Other datasets, initially taken into consideration, either did not cover the whole study area (e.g., 1930s military maps in scale 1:25,000) or had relatively poor quality (Third Military Survey Map from the late $19^{\text {th }}$ century) and therefore were not included in the analysis.

In the Swiss Alps, the oldest material used in the study was the Dufour Original Survey Map dated between 1845-1864 and created in 1:25,000 scale for the Swiss plateau and 1:50,000 for mountain areas. Forests were presented in green colour, sometimes with an additional dark-green outline. For the end of the $19^{\text {th }}$ century and the mid-20 $20^{\text {th }}$ century two editions of the Siegfried Map were selected. The Siegfried Map is the second federal map series (1870-949), with map sheets in 1:25,000 scale for the Jura and the Central Plateau and in 1:50,000 scale in the Alps. Land use and land cover information includes settlements, roads, forests, wetlands, peatlands, orchards, vineyards and unvegetated areas (glaciers, rocks). Forests were shown with small, thin graphical symbols closely spaced to each other, yielding a stylized kind of tree patterns (Leyk et al. 2006). Forest boundaries were indicated by thin lines whereas open forests were not clearly delineated. All editions of the Siegfried Map are available in a digital form (scanned and georeferenced) and have been used for historical land cover reconstructions (e.g., Gimmi et al. 2011, Ginzler et al. 2011). From 1940 onwards, the modern 'Landeskarte der Schweiz' gradually replaced the Siegfried Map (Grosjean 1996). In our study, versions compiled and published for 1970s and 2012 were chosen. For 1970s, forested areas were presented in green colour with black, solid line around the patches. For 2012 the map was available in the digital vector format from the Swiss Topographical Office (swisstopo DV033594).

\section{Production-oriented uncertainty}

Production-oriented uncertainty covers a wide range of topics of great importance for change detection results. Two aspects seem to be especially important - forest definitions and spatial effects related to cartographic generalisation.

\section{Forest definitions}

Defining "forest" is a complex problem (Lund 1999, Bennet 2001), as physical land cover, land use and geometry (e.g., area) are involved. Forest definitions frequently imply a minimum area (see e.g. Ustawa... 1991, Global... 2010). Swiss example shows that forest definition on the Siegfried Map surveys were adopted from Dufour Map (Gugerli, Speich 2002), what means that till mid-20 ${ }^{\text {th }}$ century forest included also stands of green alder and dwarfpine. On Landeskarte der Schweiz surveys (since mid-20 ${ }^{\text {th }}$ century onward) forest definition considered slightly different conditions: coverage of trees $>50 \%$ and height of trees $>3 \mathrm{~m}$. Age and use of forest was not considered.

We were not able to find a reliable reference to the original forest definition in the Second Military Survey Map. However, it is important to stress that forest patches were presented according to property boundaries (Troll 2013). Considering the other two Polish maps, forest was understood as a land use, what implies that clear-cuts were not shown. As for the minimum forest area on the oldest map, the smallest forest patch corresponded to land parcels with forest use delineated on the cadastre that was a source for the Second Military Survey Map. The Polish Military Map (1930s) defined forest as a polygon with side length of at least $30 \mathrm{~m}$ (Walczak 1946). For topographic maps from the 1970s/1980s, the guidelines defined forest as a polygon larger than 


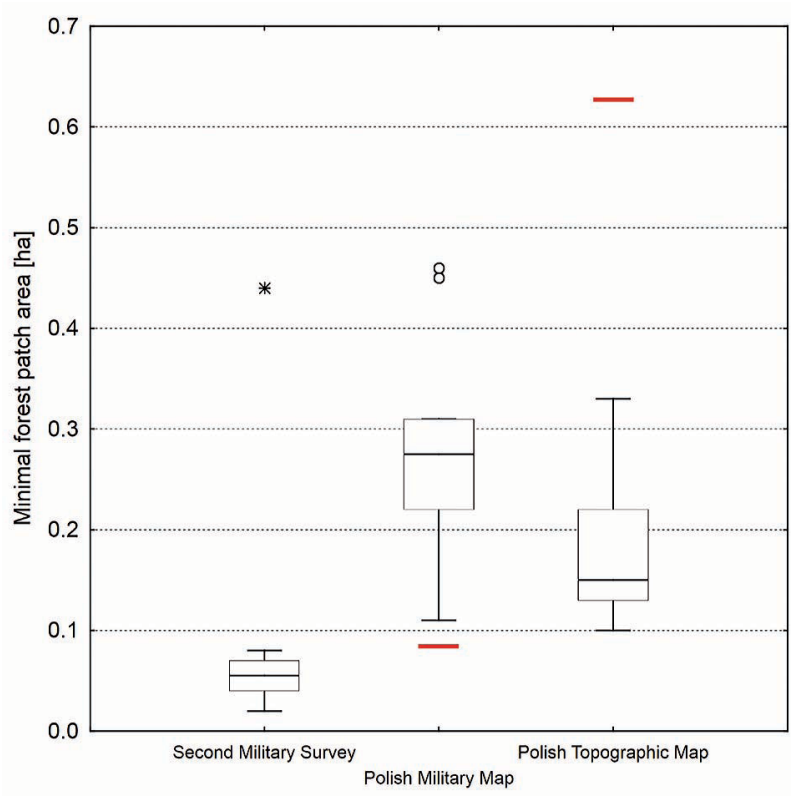

Fig. 1. Minimum forest patches for 10 randomly chosen map sheets for each map set in the Polish Carpathians; lines in red show the value defined by map instruction (not available for the Second Military Survey Map)

$10 \mathrm{~mm}^{2}(0.625$ ha in the scale of the map, Instrukcja... 1980).

Testing the materials for the Polish Carpathians, we found that the smallest forest patch on the Second Military Survey Map had 0.02 ha, and 0.5 on average (Fig. 1), on the Polish Mili- tary Map it was 0.11 ha, very close to the threshold defined by mapping guidelines, and 0.27 on average, and in case of the Polish Topographic Map the smallest forest patch had 0.1 ha, and 0.14 ha on average, exceeding in many instances the threshold specified in the guidelines. The identified smallest forest mapping units reflected both map design rules and the specific landscape patterns at the time, having important consequences for further change analysis.

\section{Spatial effects related to map production and cartographic generalisation}

One of the crucial aspects of map creation and design process is cartographic generalisation. This aspect is extremely important in our study as the scale of the Polish Military Map was significantly different to other two maps. However, being aware of the fact that the Polish Military Map was intended to replace the 1:25,000 map where the latter was not available (Przepis... 1929), we hypothesized that it may show spatial detail in a comparable way to maps in larger scale. Therefore we compared forest distribution and simple distance-based measures for 1:100,000 and
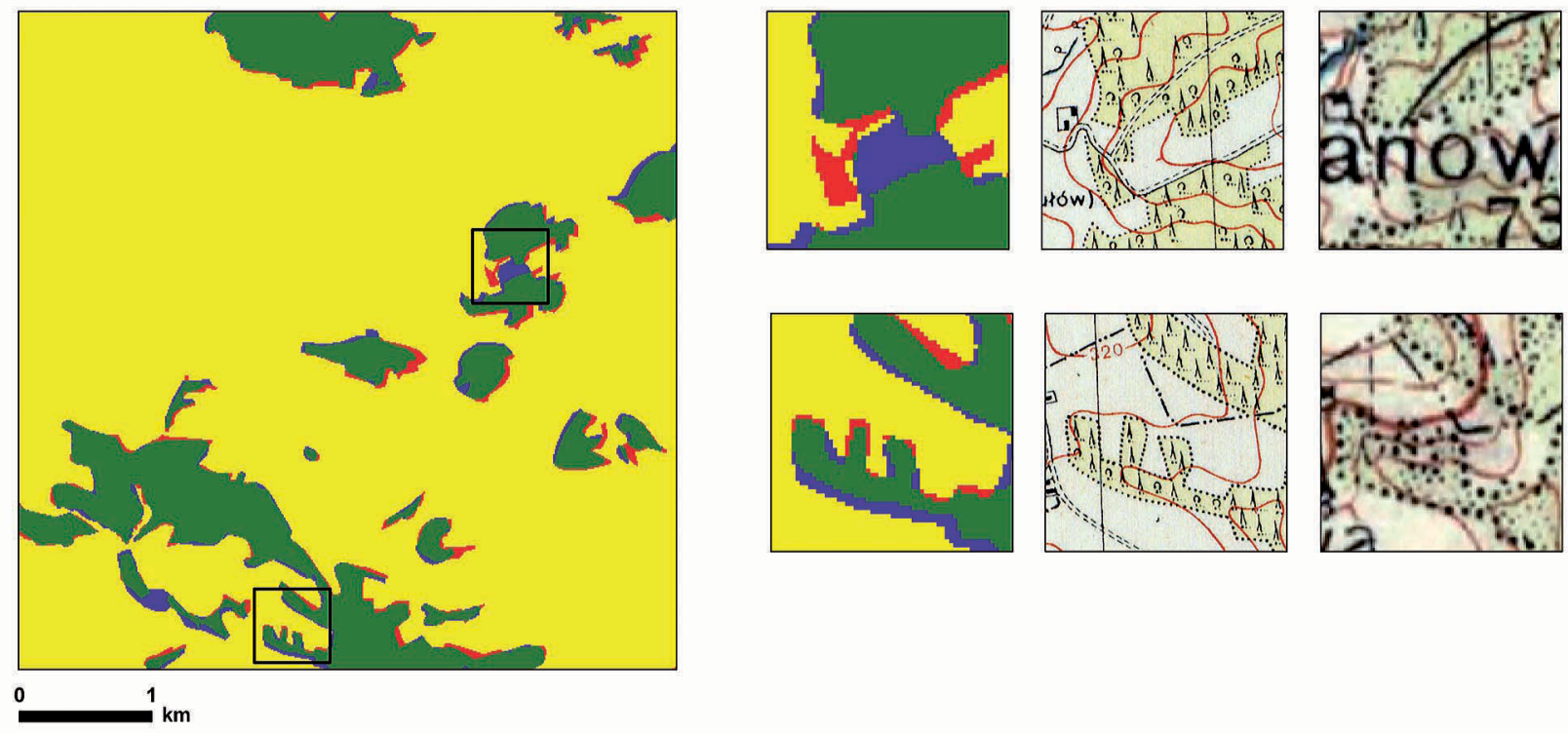

non-forest on both maps

forest on 1:100,000 map

forest on both maps

forest on 1:25,000 map

Fig. 2. Differences in forest distribution on the military maps in scale 1:100,000 and 1:25,000 in one of the test areas 
Table 1. Forest cover distribution and distance indicators on 1:100,000 and 1:25,000 maps

\begin{tabular}{|l|c|c|c|c|}
\hline & \multicolumn{2}{|c|}{ Test area 1 } & \multicolumn{2}{c|}{ Test area 2 } \\
\hline $\begin{array}{l}\text { Map scale } \\
\text { (publishing year) }\end{array}$ & $\begin{array}{c}1: 25,000 \\
(1935)\end{array}$ & $\begin{array}{c}1: 100,000 \\
(1935)\end{array}$ & $\begin{array}{c}1: 25,000 \\
(1935)\end{array}$ & $\begin{array}{c}1: 100,000 \\
(1934)\end{array}$ \\
\hline No of patches & 55 & 48 & 21 & 19 \\
\hline $\begin{array}{l}\text { Minimum distance between closest } \\
\text { patches [m] }\end{array}$ & 14.80 & 20.21 & 28.44 & 15.63 \\
\hline $\begin{array}{l}\text { Average minimum distance between 5 } \\
\text { pairs of closest patches [m] }\end{array}$ & 15.92 & 24.67 & 61.25 & 65.17 \\
\hline Forest cover [\%] & 38.66 & 38.20 & 16.08 & 15.99 \\
\hline Forest cover agreement [\%] & \multicolumn{2}{|c|}{89.8} & & 96.8 \\
\hline
\end{tabular}

1:25,000 maps ${ }^{1}$ on two $5 \times 5 \mathrm{~km}$ test sites (Fig. 2, Table 1). Distance between closest patches may be considered as an indicator of cartographic precision and the average distance between five pairs of closest patches corresponds to metrical entropy defined by Bjørke (1996). The results show that forest was mapped on both maps in a relatively consistent way with lower than expected impact of scale-driven generalisation, with surprisingly small differences between 1:100,000 and 1:25,000 maps.

\section{Transformation-oriented uncertainty}

Working on historical maps in GIS is always connected with transforming paper data into digital form (Leyk et al. 2005). Several steps of that process may result in uncertainty, in particular geo-referencing and data acquisition.

In our study data acquisition process was based on both manual vectorisation (Second Military Survey Map, Polish Military Map, Dufour Map, two editions of Siegfried Map) and automatic feature extraction (Polish and Swiss maps created in 1970s). The accuracy of automatic feature extraction was found to reach in most cases above $95 \%$ (Ostafin et al. in preparation). As for the manual vectorisation, in parallel to data control procedures (i.e. by topology rules and visual verification), independent tests were conducted for two Carpathian maps. The same group of 12 people was asked to vectorise manually the same test areas of the Polish Military Map and the Polish Topographic Map. Their results were

1 The 1:25,000 map was initiated in 1920s by the Polish Geographic Military Institute, yet only several areas in the Polish Carpathians were mapped before the World War II. then compared to the forest mask prepared by an expert. The average amount of discrepancies did not exceed $5 \%$ in case of the first map and $2 \%$ for the latter. Systematic tests were not carried out for the Second Military Survey Map, yet our experiences show that interpretation of forest boundaries is significantly more difficult and subjective for the oldest map editions than for the edition published in 1860s.

During vectorisation of the Dufour Map a problem of overlapping map sheets (with differences in delineation of forested areas) had to be solved. The base map was chosen taking into account the date of publishing (with preference to the older edition) and map quality (Fig. 3).

\section{Application-oriented uncertainty}

Comparison of different map sets is exposed to uncertainty also due to different sematic models standing behind the information we want to compare. It is highly dependent on the intended use of historical maps as well as on the map content taken into consideration. The oldest Carpathian map we used was created for military purposes (reflected e.g. in a complex road network classification), but land use information was obtained by a generalisation of cadastral mapping, implying a similarity of forest patches to parcel boundaries. Although the Polish Military Map had the same objectives, the military operations changed in time and influenced forest delimitation since the mid- $19^{\text {th }}$ century. Hence, in the 1930s, forest was perceived rather as a barrier for military troops or as an area for avoiding detection from aerial observation (Instrukcja... 1925). The Polish Topographic Map was intended to provide spatial information for regional 

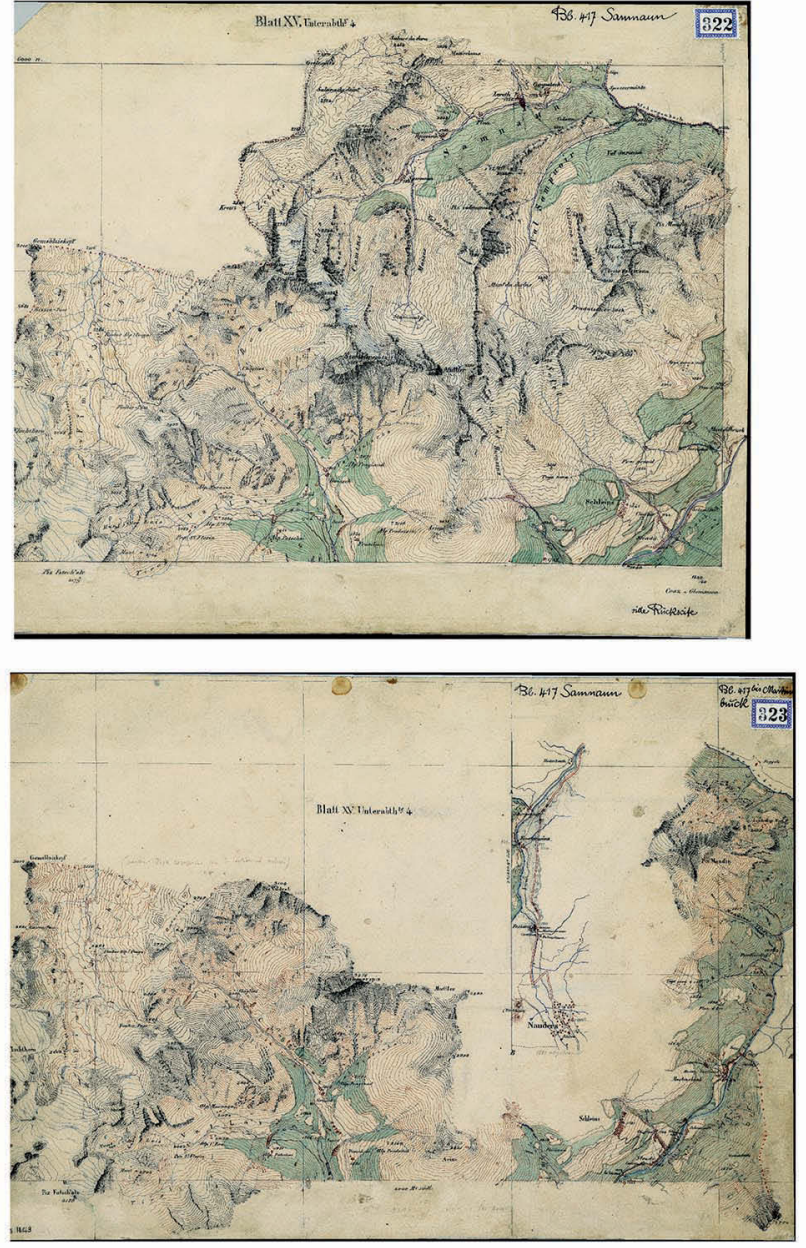

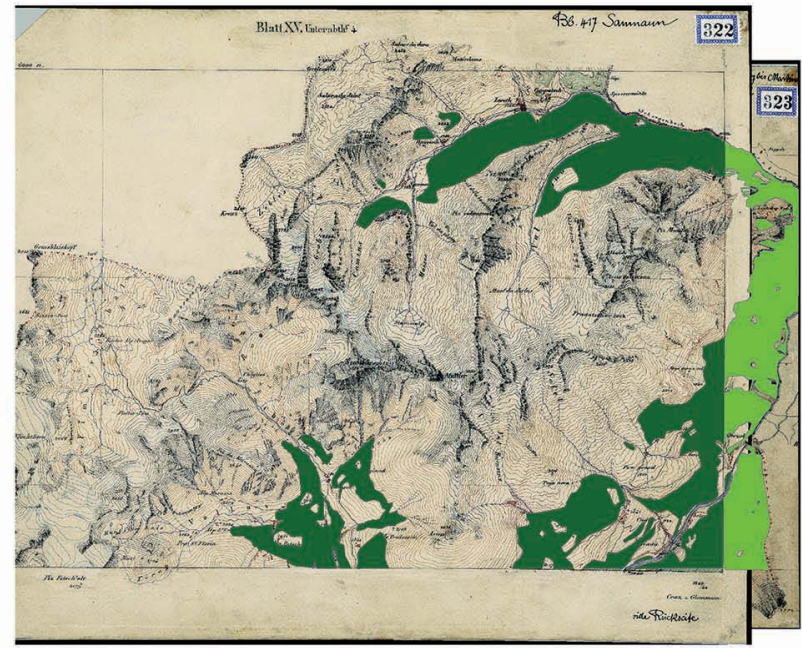

Fig. 3. Overlapping map sheets dating from 1850 (upper left) and 1849 (lower left). Due to quality issues (mapping of a larger continuous area) the overlapping area was mapped from the 1850 map (dark green) while the smaller area on the right side was only depicted on the 1849 map (light green)

planning and for economic purposes, being independent from military mapping. According to the guidelines, forest was understood as a land use and separated from group of trees.

\section{Semantic model difference - a case of Silesia}

Our analysis highlighted one specific area (Silesia), where various forest cover patterns were correlated to differences in semantic models of two editions of the Second Military Survey Map (Fig. 4).

In the western part, forest cover was relatively low and significant part of the mountains was covered by forested pastures. In the eastern part of the mountain range mapped 20 years later, the pastures were almost absent and share of forested land was significantly higher. Possible explanation of the difference might be connected rather to various semantic schemes defining forests and forested pastures in 1840s and 1860s than to real difference in landscape or rapid forest cover increase. As forest definition in the Second Military Survey Map was likely related to ownership patterns inherited from the original cadastral data, it could be significantly altered due to changes in the land ownership following the liberation of peasantry in 1848 (Kozak 2010), and significant reduction of grazing rights in forested areas.

\section{Reliability of change trajectories}

The examples above show how uncertainty investigation improves the understanding of the final land cover (or forest) change detection mod- 


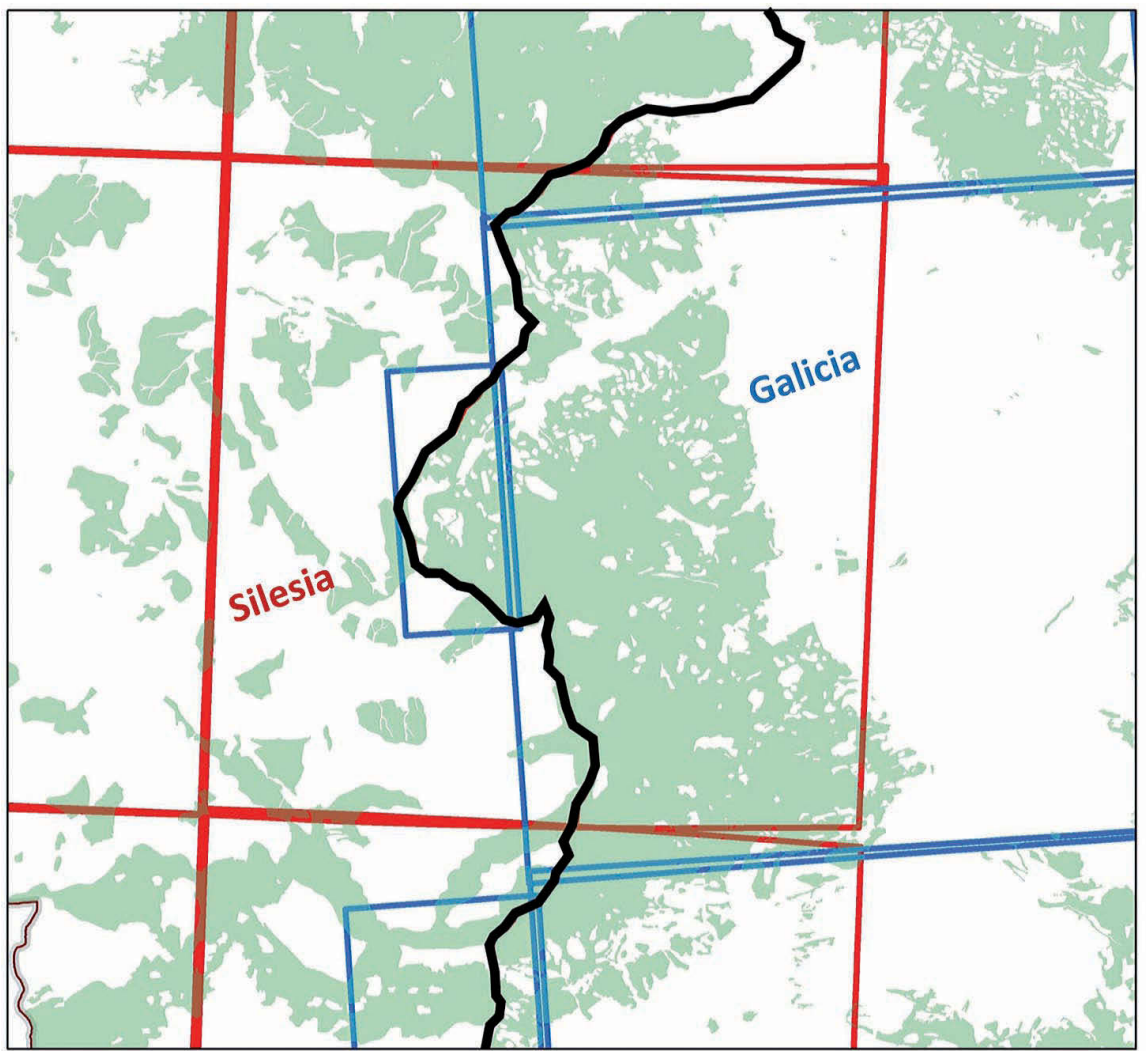

1839-1840

1861-1862

border between

Silesia and Galicia

forest cover

Fig. 4. Differences in forest cover between Silesia and Galicia shown on different editions of the Second Military Survey Map

el. Regardless the source, uncertainty affects reliability of land cover change trajectories. Therefore an alternative way of uncertainty assessment is a trajectory analysis. Its aim is to assess the reliability of a whole map-based time series using proportions of pixels falling into a specific change category. Whether a change category

Table 2. Trajectory analysis for Swiss and Polish parts of the study area (1 - forest, 0 - non-forest)

\begin{tabular}{|c|c|c|}
\hline $\begin{array}{l}\text { Trajectory - Swiss Alps } \\
(1850-1880-1940-2012)\end{array}$ & $\begin{array}{l}\text { Portion of forest } \\
\text { in } 2012\end{array}$ & $\Sigma$ \\
\hline $1-1-1-1$ & $48.7 \%$ & \multirow{4}{*}{$87.8 \%$} \\
\hline $0-1-1-1$ & $8.2 \%$ & \\
\hline $0-0-1-1$ & $7.5 \%$ & \\
\hline $0-0-0-1$ & $23.4 \%$ & \\
\hline $1-0-0-1$ & $6.9 \%$ & $94.7 \%$ \\
\hline $1-0-1-1$ & $3.0 \%$ & $97.7 \%$ \\
\hline $1-1-0-1$ & $1.7 \%$ & $99.4 \%$ \\
\hline $0-1-0-1$ & $0.6 \%$ & $100 \%$ \\
\hline $\begin{array}{c}\text { Trajectory - Polish Carpathians } \\
(1850-1930-1970)\end{array}$ & $\begin{array}{l}\text { Portion of forest } \\
\text { in } 1970\end{array}$ & $\Sigma$ \\
\hline $1-1-1$ & $54.3 \%$ & \multirow{3}{*}{$93.6 \%$} \\
\hline $0-1-1$ & $15.6 \%$ & \\
\hline $0-0-1$ & $23.6 \%$ & \\
\hline $1-0-1$ & $6.4 \%$ & $100 \%$ \\
\hline
\end{tabular}

is more or less realistic depends on the overall knowledge of the regional land use history. For the Swiss part of the study area, almost $95 \%$ trajectories ending as forest in 2012 were found to be very realistic (e.g., stable forest, or change from non-forest to forests either in 1880, 1940 or 2012) or realistic (deforestation in the first period and forest re-growth in the last period), and only 5\% represent less realistic trajectories (e.g. non-forest in 1850 and 1940 and forest in 1880 and 2012; Table 2). In the Polish Carpathians the results of similar trajectory analysis show slightly worse results than in Switzerland, as only $93.6 \%$ of the trajectories are realistic or very realistic.

While trajectory analysis does not solve all the problems resulting in uncertainty, it helps in quantifying overall consequences of various uncertainties embedded in the map-based change detection.

\section{Discussion and conclusions}

Leyk et al. (2005) suggested that the condition of fitness for use of the data has to be met in case 
of maps to conduct properly the analysis. This condition may be verified assuming that different types of guidelines and reference materials are available. If not, the uncertainty level increases. Unfortunately, historical geography is rarely data-rich (Gregory, Ell 2007) which applies especially to the oldest data sets. Hence, alternative methods to assess reliability of old maps are needed.

In this paper we highlighted selected aspects of uncertainty investigation in long-term change detection studies with maps, on a basis of forest cover change analysis in the Polish Carpathians and Swiss Alps. Investigation scheme employed was based on the conceptual framework and three uncertainty domains proposed by Leyk et al. (2005). Each uncertainty domain was analysed separately with results proving that $5-10 \%$ errors are inherent at various stages of analysis; in some cases - especially, modification of meanings of specific categories over time - they may put in doubt the results of change analysis if not carefully considered and verified against supplemental information. In other instances, the errors do not necessarily undermine the land cover change analysis: its value depends on the overall uncertainty level that is crucial to accept or reject the final results. In case of our research, preliminary results of trajectory analysis show that in the Swiss Alps only around $5 \%$ of mapped areas, and less than 7\% in the Polish Carpathians may be considered uncertain, which is an optimistic result for the reliability of forest cover change mapping and further research.

\section{Acknowledgements}

Research carried out within the FORECOM project (Forest cover changes in mountainous regions - drivers, trajectories and implications, PSRP008/2010), supported by a grant from Switzerland through the Swiss contribution to the enlarged European Union.

\section{References}

Affek A., 2011. Landscape continuity versus landscape transformation: a case study in the Wiar River catchment, Polish Carpathians (1780-2000). The Problems of Landscape Ecology 30: 147-155.
Affek A., 2013. Georeferencing of historical maps using GIS: As exemplified by the Austrian military surveys of Galicia. Geographia Polonica 86(4): 375-390.

Bennett B., 2001. What is a forest? On the vagueness of certain geographic concepts. Topoi 20: 189-201.

Bjørke J.T., 1996. Framework for entropy-based map evaluation. Cartography and Geographic Information Systems 23(2): 78-95.

Fisher P., 2003. Data quality and uncertainty: Ships passing in the night! In: Shi W., Goodchild M.F., Fisher P. (eds), Proceedings of the Second International Symposium on Spatial Data Quality. Hong Kong, Hong Kong Polytechnic University: $17-22$.

Gimmi U., Lachat T., Bürgi M., 2011. Reconstructing the collapse of wetland networks in the Swiss lowlands 18502000. Landscape Ecology 26: 1071-1083.

Ginzler C., Brändli U.-B., Hägel M., 2011. Waldflächenentwicklung der letzten 120 Jahre in der Schweiz. Schweizerische Zeitschrift für Forstwesen 162: 337-343.

Global Forest Resources Assessment 2010. Main report, FAO Forestry Paper, 163, Rome, FAO.

Goodchild M.F., 1991. Issues of quality and uncertainty. In: Muller J.C. (ed.), Advances in Cartography. London, Elsevier: 113-39.

Gregory I.N., Ell P.S., 2007. Historical GIS. Technologies, Methodologies and Scholarship. Cambridge Studies in Historical Geography. Cambridge, Cambridge University Press.

Gregory I.N., Healey R.G., 2007. Historical GIS: structuring, mapping and analyzing geographies of the past. Progress in Human Geography 31(1): 638-653.

Grosjean G., 1996. Geschichte der Kartographie. Geographisches Institut der Universität Bern, Bern.

Gugerli D., Speich D., 2002. Topographien der Nation. Politik, kartographische Ordnung und Landschaft im 19. Jahrhundert. Chronos Verlag, Zürich.

Instrukcja Techniczna K-2 - Mapy topograficzne do celów gospodarczych, 1980. Wyd. 2 Warszawa.

Instrukcja topograficzna WIG, 1925. Część II techniczna. Warszawa.

Kaim D., 2009. Zmiany pokrycia terenu na pograniczu polsko-słowackim na przykładzie Małych Pienin. Przeglad Geograficzny 81: 93-106.

Kozak J., 2003. Forest cover changes in the Western Carpathians over the past 180 years: a case study from the Orawa region in Poland. Mountain Research and Development 23: 369-375.

Kozak J., 2010. Forest Cover Changes and Their Drivers in the Polish Carpathian Mountains Since 1800. In: Nagendra H., Southworth J., (eds), Reforesting Landscapes. Linking Pattern and Process. Landscape Series 1: 253-273, Springer Verlag.

Krassowski B., 1974. Polska kartografia wojskowa w latach 1918 1945. Wydawnictwo MON, Warszawa.

Kunz M., 2006. Standaryzacja danych kartograficznych i teledetekcyjnych do analizy zmian struktury krajobrazu. Roczniki Geomatyki 6(3): 119-127.

Leyk S., Boesch R., Weibel R., 2005. A conceptual framework for uncertainty investigation in map-based land cover change modeling. Transactions in GIS 9: 291-322.

Leyk S., Boesch R., Weibel R., 2006. Saliency and semantic processing - extracting forest cover from historical topographic maps. Pattern Recognition 39(5): 953-968.

Longley P.A., Goodchild M.F., Maguire D.J., Rhind D.W., 2001. Geographic Information: Systems and Science. Chichester, John Wiley and Sons. 
Lund G.H., 1999. A 'forest' by any other name... Environmental Science \& Policy 2: 125-133.

Ostafin K., 2009. Zmiany granicy rolno-leśnej w środkowej części Beskidu Średniego od połowy XIX wieku do 2005 roku. Wydawnictwo UJ, Kraków.

Ostafin K., Iwanowski M., Cacko A., Kozak J., Gimmi U., Kaim D., Psomas A., Ginzler C., Ostapowicz K., in preparation. Detection of forest cover on historical topographic maps based on colour segmentation and morphological image processing.

Petit C.C., Lambin E.F., 2002. Impact of data integration technique on historical landuse/land-cover change: comparing historical maps with remote sensing data in the Belgian Ardennes. Landscape Ecology 17: 117-132.

Plewe B., 2002. The Nature of Uncertainty in Historical Geographic Information. Transactions in GIS 6: 431-456.

Pontius R.G., Spencer J., 2005. Uncertainty in extrapolations of predictive land change models. Environment and Planning B 32: 211-230.

Przepis podstawowy o sporzadzaniu map wojskowych $i$ opisu wojskowo-geograficznego, 1929. Wojskowy Instytut Geograficzny, Warszawa.

Skaloš J., Weber M., Lipský Z., Trpáková I., Šantrůcková M., Uhlírová L., Kukla P., 2011. Using old military survey maps to analyse long-term land cover changes - Case study (Czech Republic). Applied Geography 31: 426-438.

Timár G., 2004. GIS integration of the second military survey sections - a solution valid on the territory of Slovakia and Hungary. Kartografické listy 12: 119-126.
Troll M., 2013. Dawny austriacki kataster gruntowy w bazie danych geograficznych dla Czarnohory (Karpaty Wschodnie, Ukraina). GIS w nauce - Streszczenia konferencyjne KUL, Lublin: 10-11.

Ustawa z dnia 28 września 1991 r. o lasach., Dz.U. 101.444.

Veregin H., 1999. Data quality parameters. In: Longley P., Goodchild M.F., Maguire D.J., Rhind D.W. (eds), Geographical Information Systems: Principles, Techniques, Management and Applications (Volume 1). New York, John Wiley and Sons: 177-189.

Walczak W., 1946. Znaki topograficzne stosowane najczęściej na mapach polskich WIG oraz najważniejsze znaki na mapach bytych zaborów. Wiedza-Zawód-Kultura, Kraków.

Warcholik W., 2005. Rejestracja różnic w przebiegu granicy rolno-leśnej w Beskidzie Niskim na obszarze Polski i Słowacji (1933-1975) z wykorzystaniem GIS. Problemy Zagospodarowania Ziem Górskich 51: 59-69.

Wolski J., 2012. Błędy i niepewność w procesie tworzenia map numerycznych. Prace Komisji Krajobrazu Kulturowego 16: 15-32.

Wulf M., Rujner H., 2011. A GIS-based method for the reconstruction of the late eighteenth century forest vegetation in the Prignitz region (NE Germany). Landscape Ecology 26: 153-168.

Zhang J., Goodchild M.F., 2002. Uncertainty in Geographical Information. Taylor and Francis, London. 